\title{
ROLE OF PHASES OF MENSTRUAL CYCLE IN FATAL SELF-DIRECTED VIOLENCE
}

\author{
Jidhin V. S1, Rajeev V. M², Shilpa S. Babu³, Anwar K. A4, Neethu M. Babu5, Aiswarya Rani6, Reshma A. A7, Alfia $A^{8}$ \\ 1 Junior Resident, Department of Forensic Medicine, Government Medical College, Kottayam. \\ ${ }^{2}$ Associate Professor, Department of Forensic Medicine, Government Medical College, Kottayam. \\ 3 Junior Resident, Department of Forensic Medicine, Government Medical College, Kottayam. \\ 4 Junior Resident, Department of Forensic Medicine, Government Medical College, Kottayam. \\ $5 J u n i o r$ Resident, Department of Forensic Medicine, Government Medical College, Kottayam. \\ ${ }^{6} J u n i o r$ Resident, Department of Forensic Medicine, Government Medical College, Kottayam. \\ $7 J u n i o r$ Resident, Department of Forensic Medicine, Government Medical College, Kottayam. \\ 8Junior Resident, Department of Forensic Medicine, Government Medical College, Kottayam.
}

\section{ABSTRACT}

\section{BACKGROUND}

India accounted for the highest number of suicides in 2012, according to a report by WHO published on September 4, 2014, which also reported that one person commits suicide every 40 seconds globally. As per the report, 258,075 people committed suicide in India in 2012 of which 99,977 were female and 158,098 were male. India's suicide rate was 21.1 per 100,000 according to the report. Kerala constitutes $6.3 \%$ share of total suicides in India which is at the $4^{\text {th }}$ place, 1 st being Pondicherry $(37$ per 100,000$)$. Kerala's suicide rate is 24 per 100,000. Among the females who committed suicide, $75 \%$ were between the age group of $15-44$ years, the reproductive age group. This value clearly shows that a higher incidence of suicide occurs among females of menstruating age group. Hence, it is important to evaluate whether there is any role for menstruation or menstrual and premenstrual stress for this higher incidence. If there is any association, an intervention at the right time could bring down the suicide rate among females in the reproductive age group.

Objectives- To measure the pattern of menstrual cycle phase among cadavers of fatal self-directed violence.

\section{MATERIALS AND METHODS}

This is a descriptive study conducted at the Department of Forensic Medicine, Govt. Medical College, Kottayam during the period 09/06/2015 to 08/06/2016, during which 96 female cases of fatal self-inflicted violence cases were autopsied belonging to the reproductive age group (15-45 years). History was collected from relatives. Uterus and appendages were examined during dissection and tissue bits were sent for histopathological examination. Endometrial findings were categorised in to five groups: 1 . Lytic phase/menstrual phase; 2 . Early proliferative phase; 3 . Late proliferative phase; 4 . Early secretory phase; and 5 . Late secretory phase. The data obtained were entered in MS Excel Sheet and analysed by SPSS software.

\section{RESULTS}

Among the 96 cases included in the study, it was noted that majority of deaths were in the age group of 20 to 37 years. The cases under age group 19 years were $27.1 \%$; those between 20 -38 years were $46.9 \%$; and those above 39 were $26 \%$. Religion wise, Hindus were 57, Christians 29 and Muslims 9. Methods adopted for suicide were: hanging (49 cases); burns 22; poisoning 20; drowning 4 and one committed suicide by 'railway occurrence'. Majority of women, 40 cases (41.7\%) committed suicide during late secretory phase or premenstrual period of menstrual cycle, followed by early proliferative phase (30.2\%), late proliferative phase (13.5\%), and least in the lytic and early secretory phase (7 cases in each phase). This finding was found to be statistically significant.

\section{CONCLUSION}

Most of the global studies conducted regarding this were in Psychiatry Department among victims of non-fatal self-directed violence and these studies revealed a positive correlation between attempted suicides and premenstrual period and they attributed these results as a part of premenstrual syndrome or as a premenstrual stress response. But two related studies conducted in Kerala on completed cases of female suicide could not establish a significant association between the phase of menstruation and suicide among females. Late secretory phase of the menstrual cycle (Premenstrual period) has got maximum relation with fatal self-directed violence among females in the reproductive age group 15-45 years.

\section{KEYWORDS}

Fatal Self-directed Violence, Menstruation, Premenstrual Tension.

HOW TO CITE THIS ARTICLE: Jidhin VS, Rajeev VM, Babu SS, et al. Role of phases of menstrual cycle in fatal self-directed violence. J. Evolution Med. Dent. Sci. 2017;6(65):4707-4710, DOI: 10.14260/Jemds/2017/1019

Financial or Other, Competing Interest: None.

Submission 08-07-2017, Peer Review 01-08-2017,

Acceptance 07-08-2017, Published 14-08-2017.

Corresponding Author:

Dr. Rajeev V. M,

Associate Professor,

Department of Forensic Medicine,

Government Medical College, Kottayam-686008, Kerala.

E-mail: drrajeevvm3056@gmail.com

DOI: $10.14260 /$ jemds $/ 2017 / 1019$

\section{BACKGROUND}

Risk factors for suicide include mental illness (such as depression, personality disorder, alcohol dependence or schizophrenia) and certain physical illness. ${ }^{1}$ Over 800,000 people die by suicide every year worldwide, yet suicides are preventable. $^{2}$

It is the second leading cause of death among 15 to 29year olds and $75 \%$ of suicides occur in low and middle income countries. ${ }^{3}$ Suicide is the deliberate termination of one's existence, while in the possession and enjoyment of his 
mental faculties. Self-killing by an insane person cannot be considered as suicide. ${ }^{4}$ According to National Crime Records Bureau, there was a $23 \%$ increase in the suicide rate compared to $2002 .^{5}$ Kerala's suicide rate is 24 per 100,000 , which is significantly higher than the national average of 11.6 In the year 2012, 75\% of female suicides occurred in the 1544 years age group - the reproductive age group. This clearly shows that suicide rate is high in females of the menstruating age group. ${ }^{6}$ So it is important to identify the relationship between suicide and phases of menstrual cycle. If there is an association, intervention at the correct time could bring down the number of suicides in this vulnerable group.

\section{Objectives}

To find out role of phases of menstrual cycle in fatal selfdirected violence.

\section{Review of Literature}

Several authors have specifically hypothesised that low oestrogen levels may contribute to suicide. ${ }^{7}$ Regular menstruation is defined as menstrual cycles lasting 28 days (Standard deviation 6). ${ }^{8}$ The first day of menstruation is considered to be the beginning of menstrual cycle. The menstrual cycle is divided into follicular phase (1-11 days), mid-cyclic phase (12-16 days) and Luteal phase(17-28 \pm 3 days). ${ }^{9}$ Suicide is best understood as a multi-determined event, with biological, psychological, relationship, cultural and social factors to name a few. Vulnerability to suicide can occur along any of these vectors, including hormonal and psychological factors. ${ }^{10}$ The menstrual cycle may have a more positive association with suicidal behaviour. The effect of menstruation on suicide has been reported since 1800.11

Menstrual cycle consists of cyclical changes in the ovary and uterus. The ovarian cycle (oestrogen cycle) consists of Follicular and Luteal phases. Follicular phase is from the $1^{\text {st }}$ day of menstruation till the day of ovulation. During the Luteal phase, follicle is converted to corpus luteum. Luteal cells secrete oestrogen and progesterone. Ovarian cycle consists of changes in the endometrium. It includes menstrual phase, proliferative phase and secretory phase. Menstrual phase is the first 3 to 5 days of 28-day cycle. Proliferative phase, under the influence of oestrogen, endometrial cells proliferate rapidly. Secretory phase is the progestational phase. It is the phase from ovulation to beginning of next cycle. Proliferative phase is divided into early and late proliferative phase and secretory phase is also divided into early, mid and late secretory phase.

Premenstrual syndrome (PMS): In 1850s, Briere de Boismont and Schlager carried out the first survey to conclude that 20 to 30 percent of women suffered mood disorder before or during menses. ${ }^{12}$ Premenstrual tension was first described by Frank in 1931, and attributed it to oestrogen excess. ${ }^{13}$ For some women, the symptoms of PMS are severe enough to interfere in their lives. They have a type of PMS called Premenstrual Dysphoric Disorder (PMDD). Treatment of Premenstrual syndrome consists of exercise, dietary changes, emotional support from family and friends and medications. ${ }^{14,15}$ In a study conducted by Ducassae De et al from 232 women who were hospitalised for suicidal attempt, the proportion of PMS and PMDD were 50 and 23 percent respectively. ${ }^{16}$ Study by Lande RG, and Karamchandani $\mathrm{V}$ where exacerbation of chronic mental illness is compared with phases of menstruation established a relation between late secretory phase and precipitation of symptoms, which may lead to suicidal attempts. ${ }^{17}$ Another study by Sein Anand and Chrodrowski Z of Medical University of Gdansk, during the year 2002-03, on 151 fertile females, it was noted that suicidal attempts were most frequent among females during menstrual phase.18 A more structured study conducted at "All India Institute Of Medical Sciences, New Delhi", in 2007, where 217 autopsy specimens and same number of control population was analysed, showed that $54.5 \%$ of people who committed suicide were menstruating, compared to $6.75 \%$ of the control population. ${ }^{19}$

\section{MATERIALS AND METHODS}

\section{Study Design}

Descriptive study.

\section{Study Setting}

Department of Forensic Medicine, Govt. Medical College, Kottayam and Department of Pathology, Govt. Medical College, Kottayam.

\section{Sample Size}

During the period $09 / 06 / 2015$ to $08 / 06 / 2016$, 96 female cases of fatal self-inflicted violence cases autopsied belonging to the reproductive age group (15-45 years).

\section{Study Period}

18 months from the date of getting IEC clearance on 26/03/2015.

\section{Study Population}

All female suicide cases brought for autopsy to the Department of Forensic Medicine, Govt. Medical College, Kottayam during the study period.

\section{Inclusion Criteria}

Completed cases of female suicide in the age group of 15-45 years.

\section{Exclusion Criteria}

Bodies of Pregnant women and decomposed bodies.

\section{Study Tool}

Questionnaire administered by the investigator, autopsy instruments, plastic bottles for specimen collection, 10\% formalin, glass slides, haematoxylin-eosin stain, Microscope.

\section{Study Procedure}

Post-mortem was conducted by modified Rokitansky method. The uterus and appendages were removed. The whole dissected uterus and appendages are preserved in $10 \%$ formalin for 2 days and subjected to histopathology examination. The phase of menstrual cycle will be identified by microscopical examination and corresponding data will be noted. For study purpose uterine cycle is divided into 5 phases. 1 . Menstrual phase (1-5 days); 2 . Early proliferative phase (6-10 days); 3. Late proliferative phase (10-14 days); 4. Early secretory phase (15-21 days) and 5. Late secretory phase (22-28 days).

\section{Data Entry and Analysis}

Data entered in MS Excel and analysed by SPSS software. 


\section{RESULTS}

Age distribution of female suicide: Among the 96 female cases of suicide between the age group of 15 to 45 years, the majority of victims, 45 cases, were in the age group of 20-37 years. There were 26 cases below 19 years and 25 cases above 38 years.

\begin{tabular}{|c|c|c|}
\hline Age Group & Victims & Percentage \\
\hline$<19$ & 26 & 27.1 \\
\hline $20-37$ & 45 & 46.9 \\
\hline$>38$ & 25 & 26.0 \\
\hline Total & $\mathbf{9 6}$ & $\mathbf{1 0 0}$ \\
\hline \multicolumn{2}{|c|}{ Table 1. Age Distribution of Female } \\
Suicide Victims (15-45 years) N=96 \\
\hline
\end{tabular}

\section{Religion wise Distribution of the Victims}

Among the 96 cases of suicide victims, Hindus, 57 cases, constituted the majority (59.4\%); Christians were 29 (30.2\%); and Muslims were 9 (10.4\%).

\section{Fig 1.Religion wise distribution of Victims $\mathrm{N}=96$}

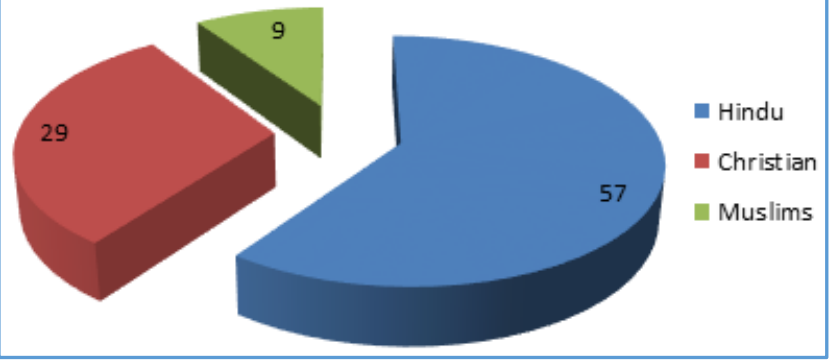

Marital Status of the victims: Among the 96 cases of female suicide victims, 58 were married, 36 unmarried and 2 cases were divorced.

\begin{tabular}{|c|c|c|}
\hline Marital Status & Victims & Percentage \\
\hline Married & 58 & $60.4 \%$ \\
\hline Unmarried & 36 & $37.5 \%$ \\
\hline Divorced & 2 & $2.1 \%$ \\
\hline
\end{tabular}

Distribution of Suicide Death According to the Phase of Menstrual Cycle

Majority of suicides occurred during the late secretory phase of menstrual cycle, 40 cases (41.7\%); followed by early proliferative phase, 29 cases (30.2\%); late proliferative, 13, (13.5\%); and 7 cases (7.3\%) each in the lytic and early secretory phases. This finding was found to be statistically significant as the $\mathrm{P}$ value is $<0.001$.

\begin{tabular}{|c|c|c|}
\hline $\begin{array}{c}\text { Stage of } \\
\text { Menstruation }\end{array}$ & Victims & Percentage \\
\hline Lytic & 7 & 7.3 \\
\hline Early proliferative & 29 & 30.2 \\
\hline Late proliferative & 13 & 13.5 \\
\hline Early secretory & 7 & 7.3 \\
\hline Late secretory & 40 & 41.7 \\
\hline \multicolumn{3}{|c|}{$\begin{array}{c}\text { Table 3. Distribution of Suicide Deaths According to the } \\
\text { Phase of Menstrual Cycle }\end{array}$} \\
\hline
\end{tabular}

$\mathrm{p}=<0.0001$

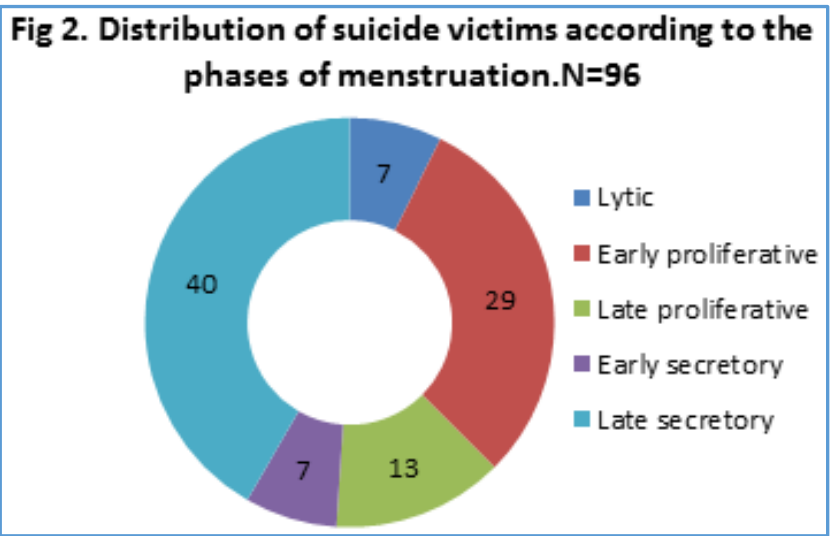

Distribution of Study sample According to the Method of Suicide Adopted

Among the 96 cases of female suicide victims, the most preferred method of suicide was hanging, 49 cases (51\%); followed by burns, 22 cases (22.9\%); poisoning, 20 cases (20.8\%); drowning, 4 cases (4.2\%); and one woman died of railway occurrence.

\begin{tabular}{|c|c|c|}
\hline Method of Suicide & Victims & Percentage \\
\hline Hanging & 49 & 51 \\
\hline Burns & 22 & 22.9 \\
\hline Poisoning & 20 & 20.8 \\
\hline Drowning & 4 & 4.2 \\
\hline Railway occurrence & 1 & 1.2 \\
\hline Table 4. Distribution of Study Sample According to the \\
Method of Suicide Adopted \\
\hline
\end{tabular}

Distribution of Study Sample According to History of Suicide

Among the 96 cases of female suicides, 41 (42.7\%) cases committed suicide impulsively according to the history given by the investigating officer, while 25 cases (26\%) suffered from some form of psychiatric illness, 19 cases gave a history of marital conflicts, 8 cases gave history of domestic violence while in 3 cases history was not conclusive.

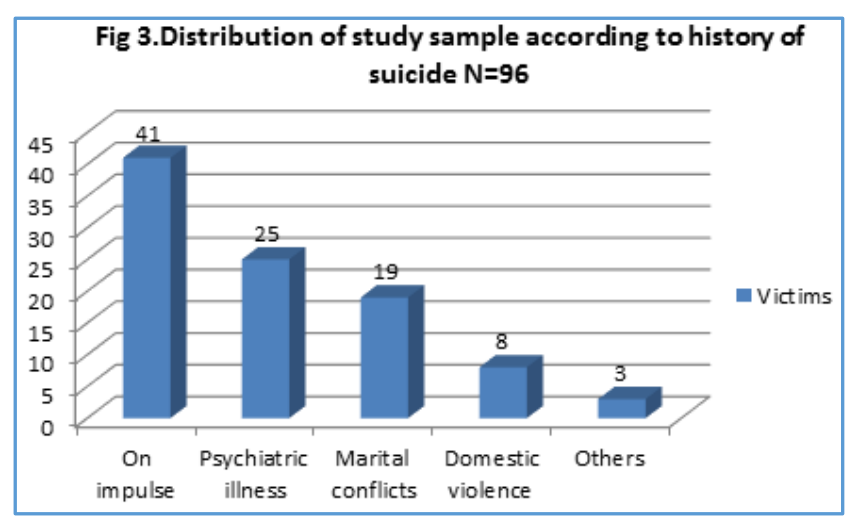

\section{DISCUSSION}

The main aim of the study was to find out the association between phases of menstrual cycle and fatal self-directed violence among females of the reproductive age group 15-45 years. Among the 96 cases brought for autopsy, it was found that majority of suicides were in the age group of 20-37 years (46.9\%). Most of the cases were from the Hindu community 
(59.4\%) followed by Christians (30.2\%), and least number of victims were Muslims (10.4\%). Majority of the victims were married (60.4\%). Majority of the suicides were in the late secretory phase (Premenstrual period) of menstrual cycle (40 cases), and the least were in the lytic and early secretory phase (7 cases each). This finding was found to be highly statistically significant. There were $30.2 \%$ cases in the early proliferative stage, and $13.5 \%$ were in the late proliferative phase. Regarding the method adopted for suicide, 49 cases were due to hanging, 22 by burns and 20 by poisoning. This shows that majority of women prefer hanging as the method of suicide. This might be due to the easy accessibility and high 'success' rate of hanging, compared to other methods. On analysing the history, it was noted that 41 females committed suicide impulsively. Psychiatric history was obtained in 25 cases and 19 cases were due to marital conflicts.

\section{CONCLUSION}

Late secretory phase of the menstrual cycle (Premenstrual period) has got maximum relation with fatal self-directed violence among females in the reproductive age group 15-45 years.

\section{REFERENCES}

[1] http://www.who.int/topics/suicide/en.

[2] http://www.who.int/mediacentre/factsheets/fs398/ en.

[3] http://www.who.int/mental_health/en/.

[4] http://thelawdictionary.org/suicide.

[5] www.ncrb.nic.in/cd_adsi2012/suicide 2.

[6] www.cdc.gov/violence prevention /pub/self-directed violence. $\mathrm{html}$.

[7] Ainsah 0, Norharlina B, Osman CB. The Association between deliberate self-harm and menstrual cycle among patients admitted to hospital Kuala Lumpur. Hong Kong J Psychiatry 2008;18(4):158-65.
[8] Bancroft J. The menstrual cycle and wellbeing of women. Soc Sci Med 1995;41(6):785-91.

[9] Baca-Garcia E, Diaz-Sastre C, de Leon J, et al. The relationship between menstrual cycle phases and suicide attempts. Psychosom Med 2000;62(1):50-60.

[10] Baca-Garcia, Diaz-Sastre, Ceverino, et al. Association between menses and suicide attempts: a replication study. Psychosomatic Medicine 2003;65(2):237-44.

[11] Brockington. Suicide in women. International Clinical Psychopharmacology 2001;16:S7-19.

[12] Gelder MG, Jaun LJ, Ibor, et al. New oxford text book of psychiatry. Vol: 11. New oxford university press 2000:P 1197.

[13] Fraser IS. The dysfunction uterus: dysmenorrhoea and dysfunctional uterine bleeding. In: Shearman PR (edr). Clinical reproductive endocrinology. Churchill Livingston 1985:579-98.

[14] http://www.medicinenet.com/script/main/art.asp/a rticle key -5031 .

[15] https://www.medlineplus.gov/premenstrual syndrome.html.

[16] Ducasse D, Jaussent I, Olie E, et al. Personality traits of suicidality are associated with premenstrual syndrome and premenstrual dysphoric disorder in a suicidal women sample. PLoS One 2016;11(2):e0148653.

[17] Lande RG, Karamchandani V. Chronic mental illness and the menstrual cycle. J Am Osteopath Assoc 2002;102(12):655-9.

[18] Anand SJ, Chodorowski Z, Ciechanowicz R, et al. The relationship between suicidal attempts and menstrual cycle in women. Przegl Lek 2005;62(6):431-3.

[19] Dogra TD, Antoon A, Aras L, et al. Menstruation and suicide: an explorative study. Psychological Reports 2007;101:430-4. 